\title{
Social network usage, shame, guilt and pride among high school students: Model testing
}

\author{
Uğur Doğan ${ }^{1}$ \\ Eyüp Çelik ${ }^{2}$ \\ Yahya Karakaş ${ }^{3}$
}

\begin{abstract}
This study was aimed at testing a model which applies structural equation modeling (SEM) to explain social networking sites (SNS) usage. Performing SEM with a sample of 500 high school students (40\% male, 60\% female), the model examined the relationships among shame, guilt and pride on SNS, such Facebook and Twitter. It was hypothesized that SNS usage was predicted directly by shame and indirectly by pride and guilt. The SEM showed that shame affected SNS usage directly and positively, while guilt and pride indirectly affected SNS via shame. The fit indices of SEM produced good fit values $\left(\chi^{2}=0.11, \mathrm{df}=2, \chi^{2} / \mathrm{df}=0.055, \mathrm{p}=0.94532\right.$, RMSEA $=0.00, \mathrm{GFI}=1.00, \mathrm{AGFI}=1.00, \mathrm{NFI}=1.00, \mathrm{NNFI}=1.00, \mathrm{CFI}=1.00, \mathrm{IFI}=1.00, \mathrm{RMR}=$ 0.039; SRMR $=0.0042)$. According to these results, high school students' feelings of shame, guilt and pride are important predictors of SNS usage.
\end{abstract}

Keywords: Social Network Sites Usage; Shame; Pride; Guilt; High School Students

\section{Introduction}

Social relationships (e.g. with peers, friends and significant others) affect psychological and physical well-being throughout life (Baumeister \& Leary, 1995; Gilbert, 2007; Siegel, 2001) and are crucial to human survival and mental health (Baumeister \& Leary, 1995; Buss, 2003). In the modern world, many individuals establish social relationships via social networking sites (SNS). Among the many ways the Internet has changed individuals' lives (Forkosh-Baruch \& Hershkovitz, 2011), social network sites (SNS) ease and enhance communication with other people (Ktoridou, Stavrides, \& Michaelidis, 2012).

SNS offer online advanced searches for individuals to find interesting opportunities, friends and appropriate environments for sharing information and conversations (Forkosh-Baruch \& Hershkovitz, 2011; Tiryakioğlu \& Erzurum, 2011). Additionally, they enable individual expression, collaboration and the formation of exciting groups (Aydogan \& Akyuz, 2010; Arquero \& RomeroFrías, 2013). Researchers have examined the use of SNS in various contexts, but only a limited

\footnotetext{
1 Assistant Professor Dr., Muğla Sttkı Koçman University, Faculty of Education, Department of Educational Science, Turkey, ugurdogn@gmail.com

2 Assistant Professor Dr., Sakarya University, Faculty of Education, Department of Educational Science, Turkey, eyupcelik@sakarya.edu.tr

3 M.A., Psychological Counselor, Marmaris Ayșe Yücel Kindergarden, Turkey, yahyapdr@yahoo.com
} 
Doğan, U., Çelik, E., \& Karakaş, Y. (2016). Social network usage, shame, guilt and pride among high school students: Model testing. International Journal of Human Sciences, 13(1), 1926-1936. doi:10.14687/ijhs.v13i1.3637

number of studies have considered the SNS usage of university students. Therefore, the present study investigated whether guilt, shame and pride predict SNS use.

Self-conscious feelings, including guilt, shame and pride (Tangney, 1991), are linked to a variety of psychopathological outcomes (Muris \& Meesters, 2014). Shame is related to aggression constructs, while guilt is linked to a propensity to assume responsibility for violations and failures (Furukawa, Tangney, \& Higashibara, 2012). In general, pride, shame and guilt are known and defined as emotions (Mauro, Sato, \& Tucker, 1992; Tracy \& Robins, 2004).

An unpleasant emotional state, guilt has been described as an agitation-based feeling, including fear, worry, anxiety and tension (Alshvang, 2011; Ferguson, Stegge, Miller, \& Olsen, 1999). It encompasses self-evaluations and self-presentation and is based on negative self-attributions when one's actions are inconsistent with social or moral norms (Tracy \& Robins, 2004; Tangney, Stuewig, \& Mashek (2007). Guilt has the adaptive function of motivating a person to modify or repair interpersonal breaks (Baumeister, Stillwell, \& Heatherton, 1994; Hoffman, 2000; Tangney, 1991). It also represses anti-social behaviour and encourages individuals to modify their behaviour as needed (Yamagishi, 2013). However, strong guilt also causes negative feelings and can lead to mental illnesses, such as depression (Baumeister et al., 1994; Bybee, 1998; Tangney, 1991).

According to Freud, guilt is the fear or emotional anxiety surrounding punishment from their father. Psychoanalytic conceptualisations posit that guilt arises from unconscious tendencies to hurt others (Alshvang, 2011). Thus, guilt is a socialising force that can lead to neurosis or mental disease. In social learning theory, guilt is considered a conditioned anxiety. Kohlberg and Piaget explained guilt based on cognition and claimed that guilt reflects anxiety over losing others' approval and that one avoids guilt by acting in a way considered moral (as cited in Yamagishi, 2013). Furthermore, guilt is an interpersonal phenomenon affected by communal relationships, and according to the interpersonal approach, guilty feelings tend to be stronger in close relationships than weak or distant ones (Baumeister et al., 1994). These feelings of guilt are often unconscious and may not result from actual transgressions. In other words, people might feel guilty even in the absence of wrongdoing (Baumeister \& Leary, 1995).

Previous studies have shown that guilt is related to donation intentions (Basil, Ridgway, \& Basil 2006; Hibbert, Andrew, Davies, \& Ireland, 2007), future emotional states (Harbaugh, Mayr, \& Burghart, 2007), altruism (Hoffman, 1982), psychological problems (O'Connor et al., 1999) and symptoms of depression and anxiety (Averill, Diefenbach, Stanley, Breckenridge, \& Lusby, 2002; Harder, Cutler, \& Rockhart, 1992; Jarrett \& Weissenburger, 1990; Jones \& Kugler, 1993; O’Connor, Berry, \& Weiss, 1999; Quiles \& Bybee, 1997).

Shame involves the dynamics of social attractiveness and competition. According to the biopsychosocial perspective, individuals with higher levels of shame are negatively perceived by others as worthless, unattractive and flawed and are at risk of being rejected, excluded, ignored or even harmed or persecuted (Gilbert, 2002b; Tangney \& Dearing, 2002). Shame can be regarded as a response to the social intimidation of being regarded as undesired, alerting individuals to disruptions in their social relationships and activating defensive responses (e.g. flight, submission, appeasement) to repair damage to one's social rank and relationships (Fessler, 2004; Gilbert, 2007b). Consequently, shame is important to individuals' social existence and self-identity (Gilbert, 2007b; Tracy \& Robins, 2004).

The biopsychosocial model has identified two types of shame: internal and external (Gilbert, 1998, 2002, 2007b). External shame is linked to how one feels about others' perceptions of oneself. In this type of the shame, the world is felt as dangerous (e.g. others will be pitiless and reject one rather than be supportive and forgiving) (Gilbert, 1998, 2002; Mikulincer \& Shaver, 2005). Internal shame is related to negative emotions and self-assessment, which are linked to one's imaginary audiences created from personal experiences with others (Tracy \& Robins, 2004; Balwin, 1997). 
Previous studies have demonstrated that both types of shame are associated with depressive symptoms (Cheung, Gilbert, \& Irons, 2004; Matos, Pinto-Gouveia, \& Duarte, 2012b).

Shame and guilt are characterised by different appraisals and attributions but are both considered negative emotions (Lazarus, 1991; Lewis, 2010). Tangney, Stuewig, and Mashek (2007) contended that guilt and shame are two distinct emotions, but Fridja, Kuipers and ter Schure (1989) highlighted their similarity as emotions. Guilt generally arises when people think that they have committed interpersonal violations and motivates them to repair any harm (Tangney \& Dearing, 2002). In contrast, shame occurs when one's expected values and goals do not met with an important other's expectations or one's own ideal self (Lewis, 2010; Tangney, Niedenthal, Covert, \& Barlow, 1998). Shame produces various feelings, such as embarrassment, inadequacy and selfcontempt (Tangney \& Dearing, 2002). Furthermore, Boudewyns, Turner, and Paquin (2013) found that shame was related to perceived devious intent and anger, whereas guilt was not.

Among the emotions which facilitate the reproduction and survival of individuals, one of the most important is pride, which has an important role in mental health, psychological functioning and prosocial behaviours (e.g. caregiving and achievement). Although the loss of pride can provoke aggression (Tracy \& Robins, 2004), pride is a positive emotion related to a sense of accomplishment, self-worth, purpose and the attainment of cherished goals and motivates responsible behaviour (Shariff, Tracy, Cheng, \& Henrich, 2010; Tracy \& Robins, 2007; Cheng, Tracy, \& Henrich, 2010; Bodolica \& Spraggon, 2011). Specifically, pride can strengthen self-esteem as individuals' behaviours are appreciated by others. The manifestation of pride may perform an adjunct adaptive function, bringing attention to a person and warning the social group that an individual deserves increased acceptance and position (Tracy \& Robins, 2004).

\section{Purpose}

Guilt, pride and shame are emotions which can enhance and support sustainable SNA usage. This paper adds to this new research area by suggesting and testing a conceptual model of the influence of guilt, pride and shame on SNS use. Structural equation modeling (SEM) is used to predict use of Twitter and Facebook, which are popular among many Internet users, and to detect the most popular SNS used by high school students to express pride, guilt and shame. The tested model is shown in Figure 1.

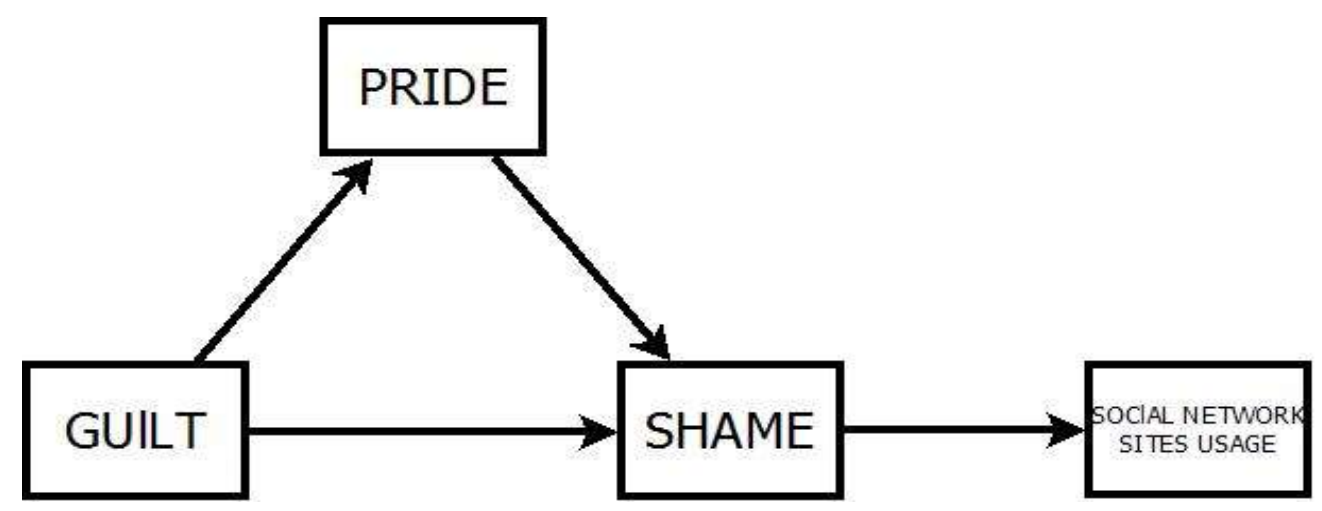

Figure 1. SEM of Significant Predictors of SNS usage (Hypothetical Model) 
Doğan, U., Çelik, E., \& Karakaş, Y. (2016). Social network usage, shame, guilt and pride among high school students: Model testing. International Journal of Human Sciences, 13(1), 1926-1936. doi:10.14687/ijhs.v13i1.3637

\section{Method and Meterial}

\subsection{Participans}

The universe of this research consisted of all high school students in Turkey during the 2013-2014 academic year. The research sample was drawn from 5 high schools randomly selected from the 15 in Bolu, Turkey. The 500 participants consisted of 500 ninth, 10th, 11th and 12th grade students from the 5 high schools in Bolu. Participants were 198 male (40\%) and 302 female $(60 \%)$ students. Data collection and analysis were conducted anonymously.

\subsection{Data Collection Tools}

Social Network Sites Questionnaire: To collect information about participants' use of SNS, they were asked two questions: 'To what extent do you use Facebook in a given day?' 'To what extent do you use Twitter in a given day?

The Trait Shame and Guilt Scale: Shame, guilt and pride was measured using the Trait Shame and Guilt Scale (Bugay \& Demir, 2011; Rohleder, Chen, Wolf, \& Miller, 2008)). This 15-item, selfreport measurement scale uses a 5 -point Likert-type scale $(1=$ not feeling this way at all; $5=$ feeling this way very strongly). Higher scores on each subscale reflect higher levels of shame, guilt and pride in each domain. Regarding the structural validity of the scale, exploratory factor analysis accounted for $63.52 \%$ total variance in the Turkish adaptation of this scale. The first factor, guilt, had 5 items and accounted for $23.59 \%$ of the variance. The second factor, guilt, had 5 items and accounted for $20.19 \%$ of variance. The third factor, pride, had 5 items and accounted for $19.72 \%$ of the variance. The results of confirmatory factor analysis show that the model fit is well suited for research in the Turkish context $\left(\mathrm{x}^{2}=87, \mathrm{~N}=205, \mathrm{p}=0.00, \mathrm{x} 2 / \mathrm{df}=2.62\right)$. The goodness of fit index values were RMSEA $=0.06$, GFI $=0.92$, CFI $=0.94$, RMR $=0.044$ and SRMR $=0.05$. Internal consistency coefficient was calculated for reliability analysis. The resulting Cronbach's alphas were 0.83 for the shame subscale, 0.81 for the guilt subscale and 0.87 for the pride subscale.

\section{3. Procedure}

Participation in the survey was anonymous and voluntary, and confidentiality was guaranteed. The data-collection tools were administered to students in their classrooms. The measures were counter-balanced in implementation. Before implementation of scales, the study objectives were told to all participants. In this research, Pearson correlation coefficients were used to determine the relationships among variables, and SEM was employed to analyse the contributions of SNS use to shame, guilt and pride in high school students.

\section{4. Data Analysis}

IBM Statistical Package for the Social Sciences (SPSS) 20.00 and the LISREL 8.80 package were used for statistical analyses of the data. Pearson correlation analysis and SEM were used to analyse the relation of SNS usage to shame, guilt and pride in high school students. The data analysis model was tested simultaneously with the available measurement data to determine the extent to which the model fit the data. The causal assumptions which form the basis of this model were verified by being tested against the data. Factor analysis, path analysis and SEM were used to demonstrate particular cases of SEM (Grimm \& Yarnold, 2000; Kline, 2005; Sümer, 2000, as cited in Erözkan, 2014). In this study, the model was constructed by using SEM to test the relationships of SNS to shame, guilt and pride in high school students. 
Doğan, U., Çelik, E., \& Karakaş, Y. (2016). Social network usage, shame, guilt and pride among high school students: Model testing. International Journal of Human Sciences, 13(1), 1926-1936. doi:10.14687/ijhs.v13i1.3637

\section{Results}

In this section, the findings concerning relationships among SNS usage, shame, guilt and pride and whether SNS predicts these variables are reported.

\subsection{Descriptive Data and Inter-correlations}

Table 1 presents the descriptive outcomes and correlation coefficients related to SNS usage, shame, guilt and pride.

Table 1. Descriptive outcomes and correlation coefficients for SEM variables

\begin{tabular}{lcccccc}
\hline Variables & Mean & Sd & $\mathbf{1}$ & $\mathbf{2}$ & $\mathbf{3}$ & $\mathbf{4}$ \\
\hline 1-SNS Usage & 2.15 & 2.17 & 1 & & & \\
2-Shame & 9.56 & 4.34 & $.13^{* *}$ & 1 & & \\
3-Guilt & 11.95 & 4.49 & $.14^{*}$ & $.62^{* *}$ & 1 & \\
4-Pride & 16.74 & 4.45 & $-.11^{*}$ & $-.34^{* *}$ & $-.15^{* *}$ & 1 \\
\hline${ }^{* *} \mathrm{p}<0.001,{ }^{* *} \mathrm{p}<0.05, \mathrm{n}=500, * *$ Facebook usage $\mathrm{M}=1.32$, Twitter usage $\mathrm{M}=.85$
\end{tabular}

Table 1 illustrates the correlations among pairs of variables in SEM. As seen, SNS use has a significant, positive relationship with shame $(\mathrm{r}=0.13)$, guilt $(\mathrm{r}=0.14)$ and significant, negative relationship with pride $(\mathrm{r}=-.11)$.

\subsection{The Prediction of SNS usage by Shame, Guilt and Pride}

Before SEM, the results of the measurement model were examined to determine whether the observed variables fit the three latent constructs (guilt, pride, shame). The model demonstrated that the fit indices of the measurement model were acceptable $\left(\chi^{2}=231.71 ; \mathrm{df}=86 ; \chi^{2} / \mathrm{df}=2.69 ; \mathrm{p}=\right.$ 0.00000 ; RMSEA $=0.05, \mathrm{NFI}=0.95, \mathrm{NNFI}=0.97, \mathrm{CFI}=0.97, \mathrm{IFI}=0.97, \mathrm{RMR}=0.076, \mathrm{SRMR}$ $=0.053$, GFI $=0.94$, AGFI $=0.92$ ). The factor loadings ranged from 0.81 to 0.50. SEM was performed to determine the relationship pattern of SNS usage, shame, guilt and pride. Figure 2 presents the final model (standardized coefficients).

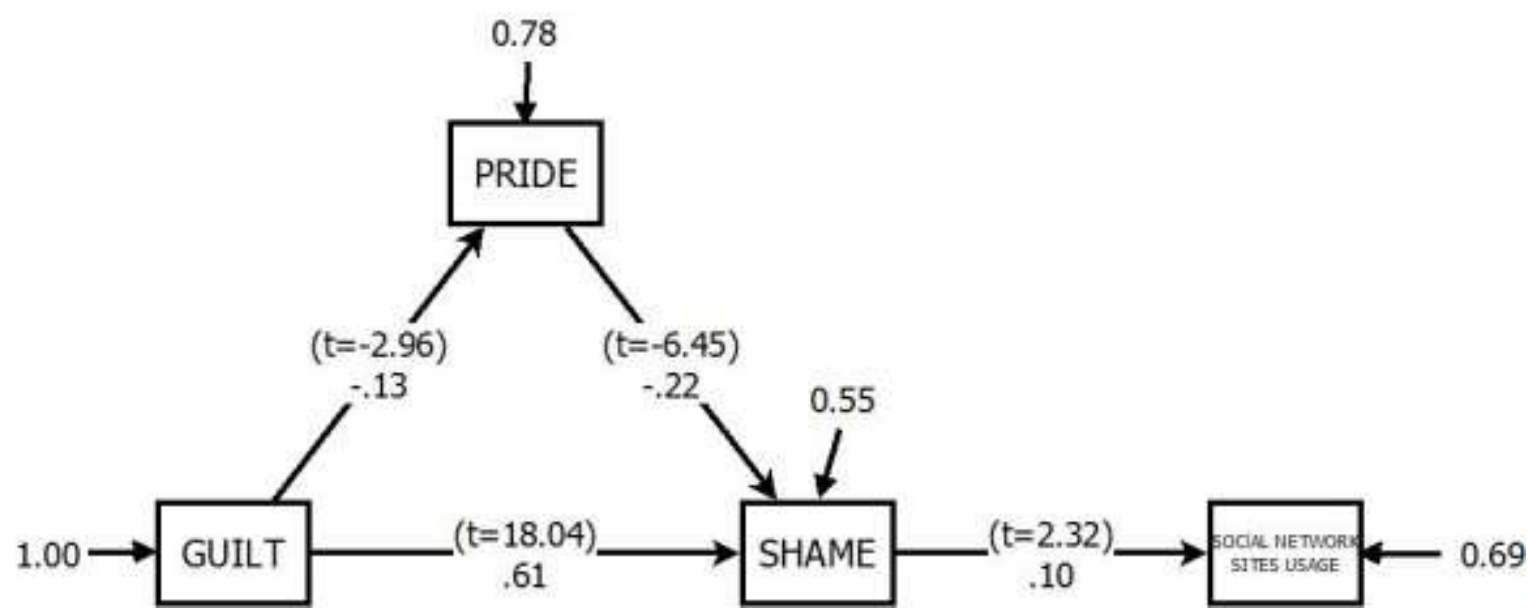

Figure 2. SEM of Significant Predictors of SNS usage (Final Model)

The research data show that the standardised coefficients of pride, shame and guilt predicted the SNS between 10 and 0.61 . Figure 2 shows whether the variables were coherent or not analysed. As seen in Figure 2, the fit indices for SEM had good fit values $\left(\chi^{2}=0.11, \mathrm{df}=2, \chi^{2} / \mathrm{df}=0.055, \mathrm{p}=\right.$ 0.94532, RMSEA $=0.00, \mathrm{GFI}=1.00, \mathrm{AGFI}=1.00, \mathrm{NFI}=1.00, \mathrm{NNFI}=1.00, \mathrm{CFI}=1.00, \mathrm{IFI}=$ $1.00, \mathrm{RMR}=0.039 ; \mathrm{SRMR}=0.0042)$. SEM coefficients ranged between 0.10 and 0.61 . 
Doğan, U., Çelik, E., \& Karakaş, Y. (2016). Social network usage, shame, guilt and pride among high school students: Model testing. International Journal of Human Sciences, 13(1), 1926-1936. doi:10.14687/ijhs.v13i1.3637

\section{Discussion}

In this study, the SEM which included the pride, guilt and shame variables was tested to explain students' SNS usage. The findings revealed a direct, significant and positive relationship between SNS use and shyness, which is one of three subdimensions of the Turkish version of the Trait of Shame and Guilt Scale. In addition, pride and guilt predicted SNS over shyness. These findings are consistent with the literature and supported by different studies (Chan, 2014; Laghi et al., 2013; Orr et al., 2008; Sheldon, 2013, 2012; Ryan \& Xenos, 2011; Wang et al., 2015; Yelpaze \& Ceyhan, 2015).

The primary reason why shy individuals prefer social media is that it eliminates many negative situations they are likely to experience in face-to-face communication, including anxiety (Bozoğlan, Demirer \& Şahin, 2013; Sheeks \& Birchmeier, 2006). Similarly, Derlega, Meets, Petronio and Marqulis (1993) found that shy individuals prefer the Internet environment as it enables hiding their true identities and reduces anxiety over rejection and humiliation.

In a study with university students, Aydin et al. (2013) investigated the relationships of loneliness and shyness with the purposes of Facebook use and found a significant, positive relationship between shyness and Facebook use. However, Facebook only enables interaction based on authentic credentials, so for the sake of comfortably expressing emotions, it might be less preferred than SNS, such as Twitter, which allow individuals to hide their true identities. Studying the relationships among shyness, social anxiety and adolescents' problematic mobile-phone usage, Deniz (2014) found a positive relationship between SNS use and shyness. Similarly, Huan et al. (2014) concluded that loneliness and shyness are the complete intermediaries of social anxiety in problematic Internet use. Based on these studies, online sharing and interactions triggered by intense feelings of shyness can lead to problematic use when uncontrolled.

According to the psychological literature, shame is among the feelings of self-awareness, and individuals use feelings, such as shame, pride, guilt and embarrassment, to prevent unwanted situations and to organise thoughts and behaviours during interpersonal relations (Tangney \& Solavey, 2000). Tangney and Dearing (2002) found that guilt and shame have significant impacts on individuals' socialising during the developmental process. Adolescents seek to feel belonging in a group while adapting to rapid changes in all developmental areas. During this process, adolescents try not to make mistakes might induce feelings of guilt, which, in turn, cause feelings of shyness. Therefore, adolescents prefer communicating via SNS where they can better control their emotions, thoughts and behaviours than in face-to-face communication.

Other findings of the present research are that shyness directly predicts SNS and that guilt and pride predict SNS over shyness. Feelings of guilt, shame and pride arise as a result of individuals' self-assessment (Eisenberg, 2000). Adolescents are undergoing a socialisation process in which they seek to be recognised by others, develop an identity of their own and gain others' approval of this identity. Adolescents also try to avoid feelings of guilt by exhibiting behaviours that do not cause miscommunication and attempt to feel better by not entering environments where they feel humiliated. SNS meets all these needs of adolescents. Individuals can better control their behaviours in online environments than face-to-face communication. It can be argued that SNS provide a platform for sustainable relations and sharing platform during socialisation (Dilmen \& Ögüt, 2010). In a scale development study on university students' purposes in SNS use, Karal and Kokoç (2013) found that individuals use SNS mostly for social interaction and communication. Öztürk and Akgün (2012) reported that individuals express themselves more comfortably in online networks than face-to-face communication. In the study by Çemrek et al. (2014), the arithmetic means for the statements 'I feel special', 'I feel more comfortable than in face-to-face communication' and 'I feel that I belong to a group' indicated that these factors have strong influence on social media. In the same study, individuals reported that social media use increased their confidence (Çemrek et al., 2014). In a study by Duran Okur and Özkul (2015), individuals 
Doğan, U., Çelik, E., \& Karakaş, Y. (2016). Social network usage, shame, guilt and pride among high school students: Model testing. International Journal of Human Sciences, 13(1), 1926-1936. doi:10.14687/ijhs.v13i1.3637

who reported that they are shy developed friendships through Facebook. Other studies have concluded that SNS use predicts shyness, socialisation and self-efficacy and that individuals disposed towards these emotions use these sites (Wang, Jackson, Wang, \& Gaskin, 2015; Sheldon, 2012). According to international studies, Facebook users are generally considered SNS users, but Facebook provides individual with fewer opportunities to interact with others while hiding their true identities. Studies performed with SNS, such Twitter, where individuals can hide their true identity obtained different results.

According to the findings concerning the overall model proposed in this paper, individuals use SNS to avoid disturbing emotions and develop more comfortable relationships, therefore enabling them to feel better. Although this situation might be beneficial and useful initially, it is suggested that it may cause individuals to pretend to be different from their true selves and consequently to become estranged from real life, resulting in a conflict between their true identities and their identities assigned by others. Frequent use of such networks for socialisation can alienate individuals from face-to-face interactions, and individuals might later experience tension due to the difficulty of expressing themselves in such environments.

This research has a few limitations. A high percentage of SNS users are high school students ages 14-19, so this study was performed with high school students, and the results cannot be generalised to all age groups. Research conducted with a sample which includes all age groups could provide more holistic results. As well, it was assumed in the analyses that all participants used SNS. Future studies could include only individuals who use SNS. In addition, this current study examined only Facebook and Twitter and the factors concerning their use, so future research could include other SNS, such as WhatsApp and Periscope. Finally, this study treated shyness, pride and guilt as factors that affect SNS use; other factors affecting SNS use could be analysed.

\section{References}

Alshvang, S. (2011). Guilt and early traumatic experiences: An investigation of empathy-based guilt in adult survivors of early parental death. (Unpublished Doctoral Thesis). The Wright Institute, California.

Andrews, B., Qian, M., \& Valentine, J. (2002). Predicting depressive symptoms with a new measure of shame: The experience of shame scale. The British Journal of Clinical Psychology, 41, 29-33.

Arquero, J. L., \& Esteban Romero-Frías, E. (2013). Using social network sites in Higher Education: an experience in business studies. Innovations in Education and Teaching International. 50(3), 238249

Averill, P. M., Diefenbach, G. J., Stanley, M. A., Breckenridge, J. K., \& Lusby, B. (2002). Assessment of shame and guilt in a psychiatric sample: A comparison of two measures. Personality and Individual Differences, 32(8), 1365-1376.

Aydin, G. S., Muyan, M., \& Demir, A. (2013). The investigation of Facebook usage purposes and shyness, loneliness. Procedia-Social and Behavioral Sciences, 93, 737-741.

Aydogan, F., \& Akyuz, A. (2010). İkinci medya çağinda Internet. Istanbul: Alfa.

Baldwin, M. W. (2005). Interpersonal cognition. New York: Guilford Press.

Baldwin, M. W. (1997). Relational schemas as a source of if-then self-inference procedures. Revien of General Psychology, 1(4), 326-335.

Bodolica, V., \& Spraggon, M. (2011). Behavioral governance and self-conscious emotions: Unveiling governance implications of authentic and hubristic pride. Journal of Business Ethics, 100(3), 535-550. 
Doğan, U., Çelik, E., \& Karakaş, Y. (2016). Social network usage, shame, guilt and pride among high school students: Model testing. International Journal of Human Sciences, 13(1), 1926-1936. doi:10.14687/ijhs.v13i1.3637

Boudewyns, V., Turner, M. M., \& Paquin, R. S. (2013). Shame-free guilt appeals: Testing the emotional and cognitive effects of shame and guilt appeals. Psychology and Marketing, 30(9), 811-825.

Bozoglan, B., Demirer, V., \& Sahin, I. (2013). Loneliness, self-esteem, and life satisfaction as predictors of Internet addiction: A cross-sectional study among Turkish university students. Scandinavian Journal of Psychology, 54(4), 313-319.

Basil, D. Z., Ridgway, N. M., \& Basil, M. D. (2006). Guilt appeals: The mediating effect of responsibility. Psychology and Marketing, 23(12), 1035-54.

Baumeister, R. F. \& Leary, M. R. (1995). The need to belong: Desire for interpersonal attachments as a fundamental human motivation. Psychological Bulletin, 117(3), 497-529.

Baumeister, R. F., Stillwell, A. M., \& Heatherton, T. F. (1994). Guilt: An interpersonal approach. Psychological Bulletin, 115(2), 243-267.

Buss, D. M. (2003). Evolutionary psychology: The new science of mind. Boston: Allyn and Bacon.

Chan, T. H. (2014). Facebook and its effects on users' empathic social skills and life satisfaction: a double-edged sword effect. Cyberpsychology, Behavior, and Social Networking, 17(5), 276-280.

Cheng, J. T., Tracy, J. L., \& Henrich, J. (2010). Pride, personality, and the evolutionary foundations of human social status. Evolution and Human Behavior, 31(5), 334-347.

Cheung, M. S. P., Gilbert, P., \& Irons, C. (2004). An exploration of shame, social rank and rumination in relation to depression. Personality and Individual Differences, 36(5), 1143-1153.

Çemrek, F., Baykuş, H., \& Özaydın, Ö. (2014). Analysis of social media use and manners in terms of uses and satisfaction approach: ESOGU Case Study. Alphanumeric Journal, 2(2), 61-76

Derlega, V. L., Meets, S., Petronio, S. \& Marqulis, S.T. (1993). Self-disclosure. London: Sage.

Dilmen, N. E., \& Öğüt, S. (2010). Sosyalleşmenin yeni yüzü: Sosyal paylaşım ağları. Marmara Üniversitesi Yeni Medya ve Etkileşim Konferansı Bildiri Kitapçŭg.

Dinçer, D. (2014). An investigation of concepts of shame among college students. (Turkish). Journal of International Social Research, 7(29), 295-311.

Deniz, S. (2014). Ergenlerin problemli mobil telefon kullanmmmn utangaçlke ve sosyal anksiyete ile iliskisinin incelenmesi (Yayımlanmamış Yüksek Lisans Tezi) İstanbul Arel Üniversitesi, Sosyal Bilimler Enstitüsü. İstanbul

Eisenberg, N. (2000). Emotion, regulation, and moral development. Annual Review of Psychology, 51(1), 665-697.

Erözkan, A. (2014). Analysis of social problem solving and social self-efficacy in prospective teachers. Educational Sciences: Theory \& Practice, 14(2), 447-455. Doi: 10.12738/estp.2014.2.2014

Eteokleous, N., Ktoridou, D., Stavrides, I., \& Michaelidis, M. (2012). Faceook - a social networking tool for educational purposes: Developing special interest groups. ICICTE Proceedings, 363375.

Ferguson, T. J., Stegge, H., Miller, E. R., \& Olsen, M. E. (1999). Guilt, shame, and symptoms in children. Developmental Psychology, 35(2), 347-357.

Fessler, D. M. T. (2004). Shame in two cultures: Implications for evolutionary approaches. Journal of Cognition and Culture, 4(2), 207-262.

Fischer, K. W., \& Tangney, J. P. (1995). Self-conscious emotions and the affect revolution: Framework and overview. In J. Tangney \& K. Fischer (Eds.), Self-conscious emotions, (pp. 324). New York, NY: Guilford Press.

Forkosh-Baruch, A., Hershkovitz, A. (2011). The use of social networks by higher-education institutes in Israel. In Y. Eshet-Alkalai, A. Caspi, S. Eden, N. Geri, \& Y. Yair (Eds.), 
Doğan, U., Çelik, E., \& Karakaş, Y. (2016). Social network usage, shame, guilt and pride among high school students: Model testing. International Journal of Human Sciences, 13(1), 1926-1936. doi:10.14687/ijhs.v13i1.3637

Proceedings of the Chais conference on instructional technologies research 2011: Learning in the technological era. Raanana: The Open University of Israel.

Fridja, N. H., Kuipers, P., \& ter Schure, E. (1989). Relations among emotion, appraisal, and emotional action readiness. Journal of Personality and Social Psychology, 57(2), 212-228.

Furukawa, E., Tangney, J., \& Higashibara, F. (2012). Cross-cultural continuities and discontinuities in shame, guilt, and pride: A study of children residing in Japan, Korea and the USA. Self and Identity, 11(1), 90-113.

Gilbert, P. (2007). Psychotherapy and counselling for depression. London: Sage.

Gilbert P (2002). Body Shame: A Biopsychosocial Conceptualisation and Overview, with Treatment Implications. In P. Gilbert \& J. Miles (Eds). Body Shame: Conceptualisation, Research and Treatment (pp. 3-54). London: Brunner.

Gilbert, P. (1998). What is shame? Some core issues and controversies. In P. Gilbert \& B. Andrews (Eds). Shame: Interpersonal behaviour, psychopathology and culture (pp. 3-36). New York: Oxford University Press.

Harbaugh, W. T., Mayr, U., \& Burghart, D. R. (2007). Neural responses to taxation and voluntary giving reveal motives for charitable donation. Science, 316(5831), 1622-1625.

Harder, D. W., Cutler, L., \& Rockart, L. (1992). Assessment of shame and guilt and their relationships to psychopathology. Journal of Personality Assessment, 59(3), 584-604.

Hibbert, S., Andrew, S., Davies, A., \& Ireland, F. (2007). Guilt appeals: Persuasion knowledge and charitable giving. Psychology and Marketing, 24(8), 723-42.

Hoffman, M. L. (2000). Empathy and moral development: Implications for caring and justice. Cambridge: Cambridge University Press.

Hoffman, M. (1982). Development of prosocial motivation: Empathy and guilt. In N. Eisenberg (Ed.), The development of prosocial behavior (pp. 281-313). NJ, England: Lawrence Erlbaum Associates.

Huan, V. S., Ang, R. P., Chong, W. H., \& Chye, S. (2014). The impact of shyness on problematic internet use: the role of loneliness. The Journal Of Psychology, 148(6), 699-715. doi:10.1080/00223980.2013.825229.

Jarrett, R. B. \& Weissenburger, J. E. (1990). Guilt in depressed outpatients. Journal of Consulting and Clinical Psychology, 58(4), 495-498.

Jones, W. H. \& Kugler, K. (1993). Interpersonal correlates of the Guilt Inventory. Journal of Personality Assessment, 61(2), 246-258.

Laghi, F. f., Schneider, B. H., Vitoroulis, I., Coplan, R. J., Baiocco, R., Amichai-Hamburger, Y., \& ... Flament, M. (2013). Knowing when not to use the Internet: Shyness and adolescents' online and off-line interactions with friends. Computers In Human Behavior, 29(1), 51-57. doi:10.1016/j.chb.2012.07.015

Karal, H., \& Kokoç, M. (2010). Üniversite öğrencilerinin sosyal ağ siteleri kullanım amaçlarını belirlemeye yönelik bir ölçek geliştirme çalışması. Turkish Journal of Computer and Mathematics Education, 1(3), 251-263.

Lazarus, R. S. (1991). Emotion and adaptation. New York: Oxford University Press.

Lewis, M. (2010). Self-conscious emotions: Embarrassment, pride, shame, and guilt. In M. Lewis, J. Haviland, \& L. F. Barrett (Eds.), Handbook of emotions (pp. 742-757). New York: Guilford Press.

Matos, M., Pinto-Gouveia, J., \& Duarte, C. (2012b). When I don't like myself: Study of the psychometric properties of the Portuguese version of the Internalized Shame Scale. The Spanish Journal of Psychology, 15(3), 1411-1423. doi: 10.5209/rev_SJOP.2012.v15.n3.39425. 
Doğan, U., Çelik, E., \& Karakaş, Y. (2016). Social network usage, shame, guilt and pride among high school students: Model testing. International Journal of Human Sciences, 13(1), 1926-1936. doi:10.14687/ijhs.v13i1.3637

Matsumoto, D., Kudoh, T., Scherer, K., \& Wallbott, H. (1988). Antecedents of and reactions to emotions in the United States and Japan. Journal of Cross-Cultural Psychology, 19(3), 267-286.

Mauro, R., Sato, K., \& Tucker, J. (1992). The role of appraisal in human emotions: A crosscultural study. Journal of Personality and Social Psychology, 62(2), 301-317.

Mikulincer, M., \& Shaver, P. (2005). Mental representations of attachment security: theoretical foundations for a positive social psychology. In M. W. Baldwin (Ed.), Interpersonal cognition (pp. 233-266). New York: Guilford.

Muris, P., \& Meesters, C. (2014). Small or big in the eyes of the other: On the developmental psychopathology of self-conscious emotions as shame, guilt, and pride. Clinical Child and Family Psychology Review, 17(1), 19-40.

O'Connor, L. E., Berry, J. W., \& Weiss, J. (1999). Interpersonal guilt, shame, and psychological problems. Journal of Social and Clinical Psychology, 18(2),181-203.

Okur, H. D., \& Özkul, M. (2015). Modern iletişimin arayüzü: sanal iletişim sosyal paylaşım sitelerinin toplumsal ilişki kurma biçimlerine etkisi (Facebook örneği). Journal of Süleyman Demirel University Institute of Social Sciences Year, 1(21), 213-246.

Orr, E. S., Sisic, M., Ross, C., Simmering, M. G., Arseneault, J. M., \& Orr, R. R. (2009). The influence of shyness on the use of Facebook in an undergraduate sample. Cyberpsychology \& Behavior, 12(3), 337-340. doi:10.1089/cpb.2008.0214.

Öztürk, M., \& Akgün, Ö. E. (2012). Üniversite öğrencilerinin sosyal paylaşım sitelerini kullanma amaçları ve bu sitelerin eğitimlerinde kullanılması ile ilgili görüşleri. Sakarya University Journal of Education, 2(3), 49-67.

Quiles, Z. N. \& Bybee, J. (1997). Chronic and predispositional guilt: Relations to mental health, prosocial behavior, and religiosity. Journal of Personality Assessment, 69(1), 104-126.

Ryan, T., \& Xenos, S. (2011). Who uses Facebook? An investigation into the relationship between the Big Five, shyness, narcissism, loneliness, and Facebook usage. Computers in Human Behavior, 27(5), 1658-1664.

Sheeks, M. S., \& Birchmeier, Z. P. (2007). Shyness, sociability, and the use of computer-mediated communication in relationship development.CyberPsychology \& Behavior, 10(1), 64-70.

Shariff, A. F., Tracy, J. L., Cheng, J. T., \& Henrich, J. (2010). Further thoughts on the evolution of pride's two facets: A response to Clark. Emotion Review, 2(4), 399-400.

Siegel, D. J. (2001). The developing mind: How relationships and the brain interact to shape who we are. New York, London: The Guildford Press.

Sheldon, P. P. (2013). Voices that cannot be heard: Can shyness explain how we communicate on Facebook versus face-to-face?. Computers In Human Behavior, 29(4), 1402-1407. doi:10.1016/j.chb.2013.01.016.

Sheldon, P. P. (2012). Profiling the non-users: Examination of life-position indicators, sensation seeking, shyness, and loneliness among users and non-users of social network sites. Computers in Human Behavior, 28(5), 1960-1965. doi:10.1016/j.chb.2012.05.016.

Smith, C. A., \& Ellsworth, P. C. (1985). Patterns of cognitive appraisal in emotion. Journal of Personality and Social Psychology, 48, 813-838.

Tangney, J. P. (1991). Moral affect: The good, the bad, and the ugly. Journal of Personality and Social Psychology, 61, 598-607.

Tangney, J. P., Niedenthal, P. M., Covert, M.V., \& Barlow, D. H. (1998). Are shame and guilt related to distinct self-discrepancies? A test of Higgins's (1987) hypotheses. Journal of Personal and Social Psychology, 75(1), 256-268. doi: 10.1037/0022-3514.75.1.256 
Tangney, J. P, \& Salovey, P. (2000). Problematic social emotions: Shame, guilt, jealousy, and envy, The Social Psychology of Emotional and Behavioral Problems. ed. Robin M. Kowalski \& Mark R. Leary, Washington, D.C.: American Psychological Association.

Tangney, J. P., \& Dearing, R. L. (2002). Shame and guilt. New York, NY: Guilford Press.

Tangney, J. P., Stuewig, J., \& Mashek, D. J. (2007). What's moral about the self-conscious emotions?. In Jessica L. Tracy, Richard W. Robins, \& June P. Tangney (Eds.), Self-conscious emotions: Theory and research (pp. 21-37). New York: Guilford Press.

Tiryakioğlu, F., \& Erzurum, F. (2011). Use of social networks as an education tool. Contemporary Educational Technology, 2(2), 135-150.

Tracy, J. L., \& Robins, R. W. (2004). Putting the self into self-conscious emotions: A theoretical model. Psychological Inquiry, 15(2), 103-125.

Tracy, J. L., \& Robins, R. W. (2007). The psychological structure of pride: A tale of two facets. Journal of Personality and Social Psychology, 92(3), 506-525.

Wallbott, H. G., \& Scherer, K. R. (1988). How universal and specific is emotional experience? Evidence from 27 countries and five continents. In K. R. Scherer (Ed.), Facets of emotion: Recent research (pp. 31-56). Hillsdale, NJ: Lawrence Erlbaum Associates, Inc.

Wang, J., Jackson, L. A., Wang, H., \& Gaskin, J. (2015). Predicting social networking site (SNS) use: Personality, attitudes, motivation and internet self-efficacy. Personality and Individual Differences, 80, 119-124. doi:10.1016/j.paid.2015.02.016.

Yamagishi, A. (2013). Four types of guilt and guilt in the Japanese. Japanese Journal of Personality, 22(3), 213-225.

Yelpaze, İ., \& Ceyhan, E. (2015). The Investigation of the relationship between personality and patterns of facebook usage: A review article. Anadolu Journal of Educational Sciences International, 5(2), 24-53. 